\title{
Evaluation of Western Shale-Oil Residue as an \\ Additive to Petroleum Asphalt for Use as a Pavement Crack and Joint Sealant Material
}

\author{
Topical Report
}

P. M. Harnsberger

J. M. Wolf

R. E. Robertson

Work Performed Under Contract No.: DE-FC21-86MC11076

\author{
For \\ U.S. Department of Energy \\ Office of Fossil Energy \\ Morgantown Energy Technology Center \\ P.O. Box 880 \\ Morgantown, West Virginia 26507-0880 \\ By \\ University of Wyoming \\ Western Research Institute \\ P.O. Box 3395 \\ Laramie, Wyoming 82071
}

November 1992 


\section{TABLE OF CONTENTS}

\section{Page}

LIST OF TABLES AND FIGURES......................................................................... iii

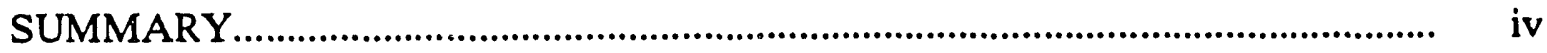

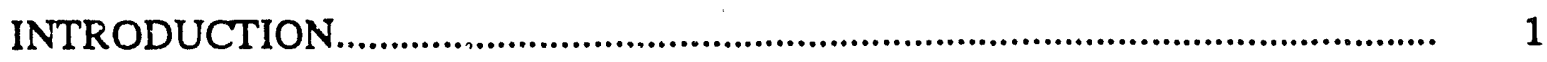

EXPERIMENTAL

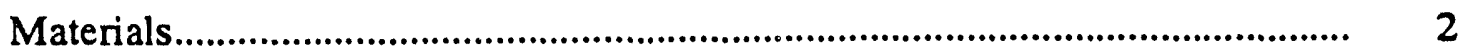

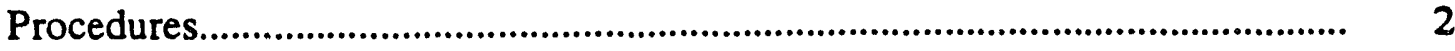

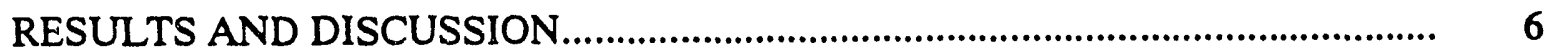

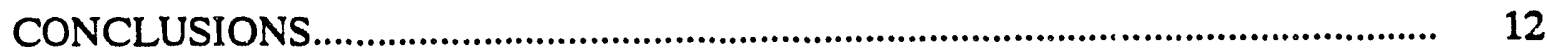

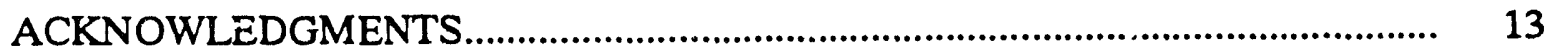

DISCLAIMER ............................................................................................. 13

REFERENCES........................................................................................... 


\section{LIST OF TABLES AND FIGURES}

Table

$\underline{\text { Page }}$

1. Results of ASTM D 3407 Extension and Resilience Testing on

Unaged Materials.

2. Results of ASTM D 3407 Extension Testing on Asphalt Samples After

6-Hour Extended Heating.....................................................................................

3. Relaxation Times and Percent Recovery Data from Portland Cement Concrete-Asphalt Briquets.

9

Figure

Page

1. Diagram Showing the Placement of Spacers During the Preparation of

Extension Test Specimens

2. Diagram Showing the Placement of Spacers During Recompression of Extension Specimens Using the Dead Mass of the Upper Block..

3. Relaxation Time versus Temperature for Portland Cement

Concrete-Asphalt Briquets.

4. Percent Recovery versus Temperature for Portland Cement

Concrete-Asphalt Briquets. 


\section{SUMMARY}

The objective of this study was to perform a preliminary evaluation of using a distillation residue from Green River Formation (western) shale oil as an additive to a petroleum asphalt for use as a crack and joint filler material in portland cement concrete and asphaltic pavements. A commercially available rubberized asphalt crack and joint filler material was also tested for comparison. ASTM specification tests for sealant materials used in concrete and asphalt pavements were performed on the sealant materials. Portland cement concrete briquets prepared with an asphalt material sandwiched between two concrete wafers were tested in a stress-relaxation experiment to evaluate the relaxation and recovery properties of the sealant materials. The results show that the shale-oil modified petroleum asphalts and the neat petroleum asphalt do not pass the extension portion of the ASTM test; however, there is indication of improvement in the adhesive properties of the shale-oil modified asphalts. There is also evidence that the addition of shale-oil residue to the petroleum asphalt, especially at the $20 \%$ level, improves the relaxation and recovery properties compared with the petroleum asphalt. 


\section{INTRODUCTION}

In the United States today, there are over 2 million miles of paved roads (The Asphalt Institute 1989). There has been much national attention focused on the deterioration of the infrastructure of the United States and more specifically, the decay of roads and bridges. Billions of dollars are spent annually by the states and the federal government to maintain, reconstruct, and construct these highways. It is not uncommon for major highway reconstruction costs to be $\$ 1$ million or more per mile of highway. Therefore, it is of paramount importance to properly maintain and repair the roadways that are currently performing to an acceptable level to extend their useful lifetime and delay the very costly reconstruction process.

All highways, regardless of whether the material is asphalt concrete or portland cement concrete, suffer from cracking during their useful lifetime. Cracking can be caused by a variety of problems, some of which are thermal expansion and contraction, moisture, repeated heavy loads, or inadequate subgrade. In addition to cracking, portland cement concrete pavements also have sawed joints at specific intervals to help relieve stresses that normally occur during service. However, these cracks and joints can provide an access point for surface water to enter the subgrade and cause pavement damage by loss of subgrade structural strength or by freeze-thaw action. Water entering through a crack or joint in a pavement also increases the likelihood of the pavement pumping or faulting. Most pavement engineers tend to underestimate the amount of surface water that can enter the structural section from above (Hogan 1980). There are other problems that can occur as a result of unsealed joints or cracks. Regarding pavement deterioration from unsealed joints, Wolters (1974) stated that the most noticeable problem is joint spalling caused by the infiltration of water and incompressible materials into the joints. As foreign material builds up in a joint and as the diurnal temperature rises, tremendous pressures are created that cause pavement to fracture at the interfaces. This is commonly known as a "blow up".

Crack and joint sealing can be considered as both corrective and preventive maintenance. Sealing can correct an existing problem of a leaking surface and help to prevent or slow the development of more serious pavement problems. The consensus of transportation agencies in most states is that crack and joint resealing is beneficial and should be performed. Unfortunately, the cost effectiveness of the procedures has not been documented. However, crack and joint sealing is considered effective for extending pavement life and reducing deterioration (Peterson 1982). Although many different types of crack and joint sealant materials have been used, the most common materials in use today are asphalt cements, rubberized asphalts, and silicone rubber. The latter two materials are significantly more expensive than asphalt cement. Preformed joint sealants can also be used in portland cement concrete pavements but these can be expensive both in terms of material cost and installation time. 
The purpose of this investigation was to determine if western shale-oil residue added to petroleum asphalt could improve the performance of the asphalt when it is used as crark and joint filler material. The most frequent cause of sealant failure is adhesion (or bond) failure (Peterson 1982). Previous work at Western Research Institute indicates that western shale-oil modified petroleum asphalts show increased adhesive properties on aggregate surfaces (Plancher and Petersen 1984). If western shale-oil addition increases the performance of conventional asphalt, the benefits from the improved performance could offset the cost of the shale oil. In addition, another potential use and market for western shale oil would be identified.

\section{EXPERIMENTAL}

\section{Materials}

\section{Shale-Oil Additive}

The western shale-oil additive was obtained from The New Paraho Corporation and was produced from freshly retorted Green River formation shale. The whole shale oil was vacuum distilled to produce $\mathrm{a}+371^{\circ} \mathrm{C}\left(+700^{\circ} \mathrm{F}\right)$ residue, then further processed by a proprietary method to produce a specification-grade AC-20 asphalt additive.

\section{Petroleum Asphalt}

The petroleum asphalt was an AC-20 grade that was obtained from the Sinclair refinery in Sinclair, Wyoming.

\section{Rubberized Asphaltic Material}

The rubberized asphaltic material used for comparison pu : 3 ses was obtained from a commercial supplier and is a standard specification-grade crac - and joint filler material.

\section{Procedures}

\section{Preparation of Portland Cement Concrete Test Specimens}

Procedure C 192 (ASTM 1991a) was followed to prepare portland cement concrete blocks for extension testing of the crack and joint sealant materials. Concrete slabs 30.48 $\mathrm{cm}(1 \mathrm{ft})$ square and $7.62 \mathrm{~cm}$ ( $3 \mathrm{in}$.) thick were poured and finished. The slabs were covered with plastic and cured in a $100 \%$ humidity chamber for 25 days. The forms were removed after 48 hours. After curing, $2.54 \times 5.08 \times 7.62 \mathrm{~cm}(1 \times 2 \times 3$ in.) blocks were cut using a water-cooled, masonry saw equipped with a diamond-impregnated blade. These blocks were stored in saturated lime water solution until used. 
Concrete disks measuring $4.45 \mathrm{~cm}$ (1.75 in.) in diameter which were used in the briquet testing were prepared by coring the concrete slabs using a carbide-tipped, coring tool. The cores were then sawed into $1.27 \mathrm{~cm}(0.5 \mathrm{in}$.) slices using a water-cooled masonry saw equipped with a diamond-impregnated blade.

\section{Preparation of Shale-Oil Blends}

Blends of 10 and 20 wt \% shale oil with AC-20 asphalt were prepared by weighing the appropriate amounts of each constituent into quart cans. The total amount of each blend prepared was 800 grams. The empty space remaining in each can was purged with argon gas. The cans were heated for a total of 5 hours in a $150^{\circ} \mathrm{C}\left(302^{\circ} \mathrm{F}\right)$ oven. The cans were removed from the oven every hour and shaken in a paint shaker for a period of 5 minutes.

\section{Extension Testing}

Test specimens were prepared following procedure D 3407 (ASTM 1991b) Each sample was tested in triplicate with three cycles of extension and compression constituting a complete test. Briefly, a sample was heated in a $150^{\circ} \mathrm{C}\left(302^{\circ} \mathrm{F}\right)$ oven for approximately 1 hour or until fluid. It was then poured into a mold formed with the portland cement concrete blocks and metal spacers. The metal spacers are $1.27 \mathrm{~cm}(0.5$ in.) thick and were used to define a space between the concrete blocks $5.08 \mathrm{~cm} \times 5.08 \mathrm{~cm}$ ( 2 in. $x 2$ in.). As shown in Figure 1, the mold was formed using six spacers as follows: two were placed underneath each concrete block, two were used to separate the blocks, and the remaining two were placed on top of each block as sidewalls so that an excess of asphalt could be poured into the mold. Rubber bands and metal clamps were used to hold the molds together. The metal spacers were coated with a mixture of glycerin and talc for easy removal from the asphalt. The filled molds were cooled for 2 hours at room temperature. A hot knife was then used to trim off the excess asphalt. The trimmed specimens were placed in the extension machine and cooled to the test temperature ($20^{\circ} \mathrm{C} /-4^{\circ} \mathrm{F}$ ) for 4 hours. The extension machine was started and the specimens were pulled at a rate of $0.3175 \mathrm{~cm}(1 / 8 \mathrm{in}$.) per hour for 2 hours. After the samples were extended, they were removed from the extension machine and placed flat on one of the concrete blocks. Two spacers, one on each side, were put in between the concrete blocks of each sample to allow the sample, as shown in Figure 2, to return to its original thickness. Compression of the samples was achieved using the dead mass of the upper concrete block. The asphalt samples were compressed at room temperature for 2 hours by the upper block. If no failure was observed after extension and recompression of the a phalt sample, the sample was retested following the same procedure until three cycles had been completed. 


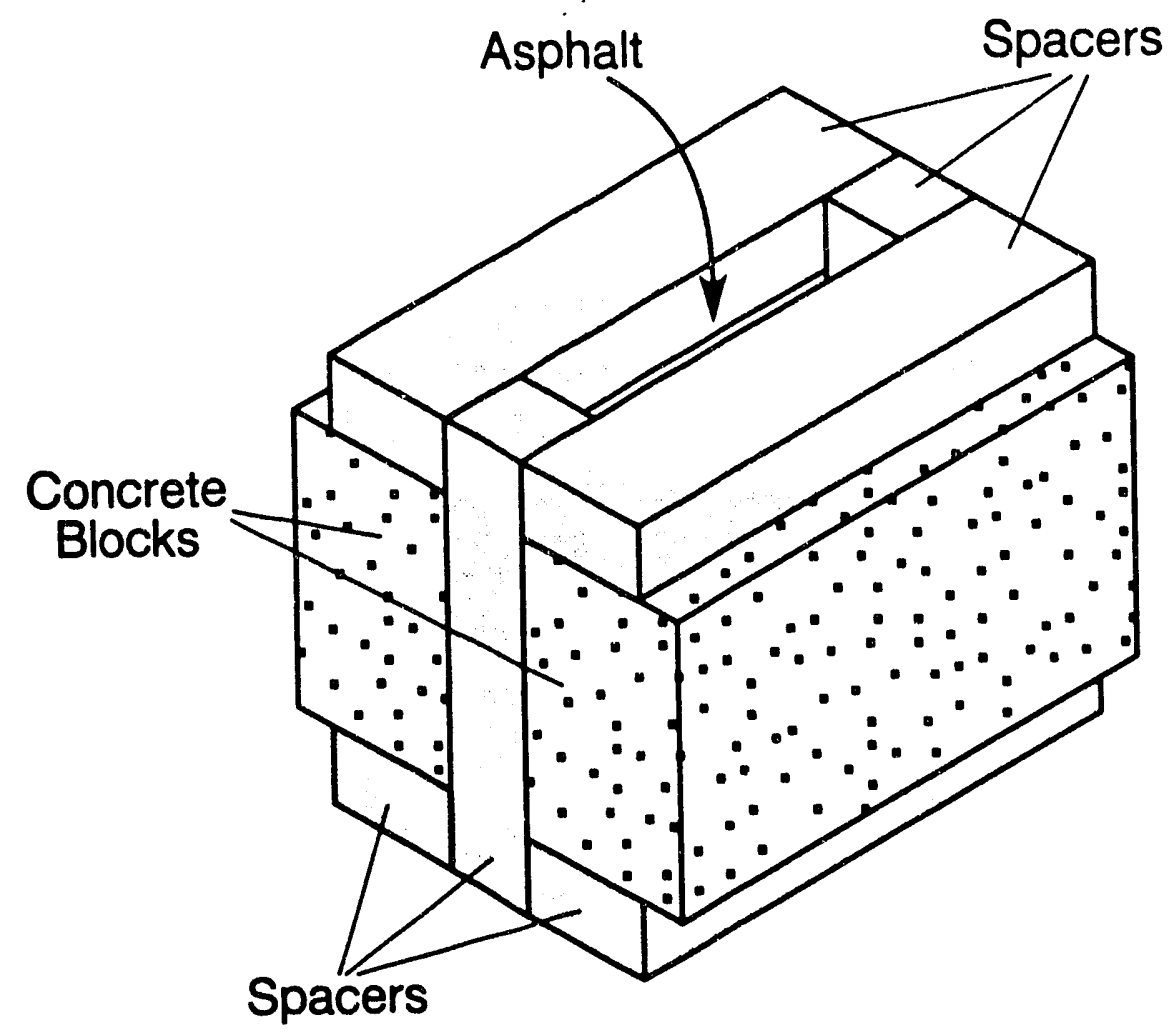

Figure 1. Diagram Showing the Placement of Spacers During the Preparation of Extension Test Specimens

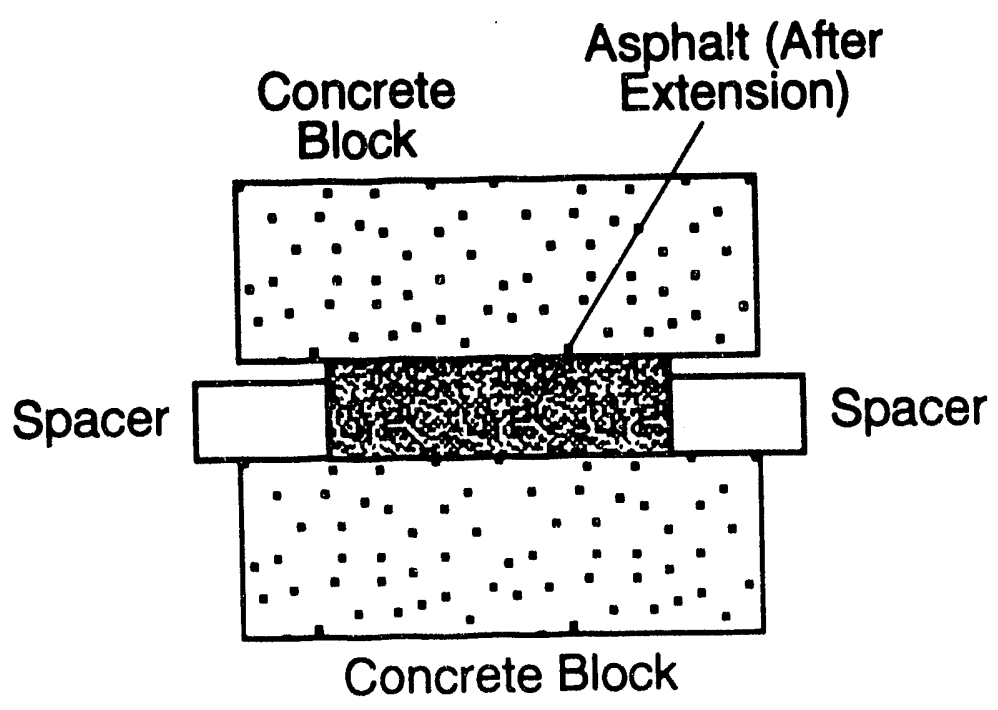

Figure 2. Diagram Showing the Placement of Spacers During Recompression of Extension Specimens Using the Dead Mass of the Upper Block 


\section{Extended Heating of Samples for Extension Testing}

Samples were heated and mixed with a paddle stirrer for 6 hours in a $150^{\circ} \mathrm{C}\left(302^{\circ} \mathrm{F}\right)$ oven to simulate day-long heating in a hot-applicator pot. This procedure is part of the requirements of Method D 3407 (ASTM 1991b). Extension test samples were prepared using the 6 hour-heated asphalt and tested as described above.

\section{$\underline{\text { Resilience Testing }}$}

Resilience testing was performed according to Method D 3407 (ASTM 1991b) which is a modification of the standard penetration Test D 5 (ASTM 1991c). This test uses a specifically designed ball penetration tool. The ball penetration tool is a $1.7 \mathrm{~cm}$ $(0.675 \mathrm{in}$.) diameter steel ball attached to a $6.81 \mathrm{~cm}$ (2.68 in.) shaft weighing a total of 75.0 grams. The ball penetration tool is used in a regular penetrometer in place of the standard penetration needle. Samples were poured into $6 \mathrm{oz}$. ointment cans and conditioned for 1 hour in a $25^{\circ} \mathrm{C}\left(77^{\circ} \mathrm{F}\right)$ water bath prior to testing. Determinations were performed by placing the ball in contact with the surface of the asphalt and then releasing it for five seconds. The ball was then pushed an additional 100 units (decimillimeters) into the asphalt over a time period of approximately 10 seconds. The dial indicator was then returned to zero and the sample was allowed to recover for 20 seconds before the final reading was recorded. Three determinations were made on each sample and the results were averaged.

\section{Preparation of Portland Cement Concrete-Asphalt Briquets}

A circular Teflon ${ }^{\circledR}$ form was placed around one concrete disk. The form extended above the top of the disk $0.5 \mathrm{~cm}\left(0.2 \mathrm{in}\right.$.). A sample of asphalt was heated at $140^{\circ} \mathrm{C}$ $\left(284^{\circ} \mathrm{F}\right)$ in an oven for approximately 20 minutes or until fluid and then poured into the form until just level with the top. The sample was allowed to cool at room temperature overnight and the following morning, the form was removed from the sample. A second concrete disk was heatec at $140^{\circ} \mathrm{C}\left(284^{\circ} \mathrm{F}\right)$ in an oven for 5 minutes, removed from the oven, and carefully placed on top of the asphalt portion of a previously prepared sample. The completed briquet was allowed to cool to room temperature for 1 hour before testing.

\section{Rheologic Testing of Briquets}

The portland cement concrete-asphalt briquets were mounted into a Brabender Rheotron. The briquets were conditioned at $25^{\circ} \mathrm{C}\left(77^{\circ} \mathrm{F}\right)$ for at least 1 hour before commencing the test. At the lower temperatures of $0^{\circ}$ and $10^{\circ} \mathrm{C}\left(32^{\circ}\right.$ and $\left.50^{\circ} \mathrm{F}\right)$ the briquets were conditioned for at least 2 hours. A constant torque was applied to one of the concrete disks and the transmitted or resultant torque was recorded on a strip-chart recorder. Torque was applied to the sample until a constant slope was recorded and then held in that relative position until the transmitted torque decayed to zero or near zero. Rheologic measurements calculated from the recorded curve were relaxation time and percent recovery. 


\section{RESULTS AND DISCUSSION}

The results from D 3407 (ASTM 1991b) extension and resilience testing on the unaged samples are shown in Table 1. Method D 3407 (ASTM 1991b) is the standard test method for testing hot-poured joint sealants for concrete and asphalt pavements. The data show that the AC-20 asphalt and the two levels of shale-oil modified AC-20 asphalts do not pass the extension testing in this method. However, observation of the test specimens after failure did provide some insight into the materials. The AC-20 asphalt showed both cohesive failure (within the asphalt) and adhesive failure (asphalt-concrete block interface) on all three test specimens. There was a substantial amount of adhesive failure on ail three specimens. Both levels of shale-oil modified AC-20 asphalt, 10 and $20 \%$, showed no adhesive failure and only cohesive failure. Although the AC-20 and the shale-oil modified AC-20 asphalts all exhibited failure during the first cycle of extension, there was substantial difference between these materials. The apparent increase of adhesive quality of the shale-oil modified asphalts found in this study supports the same finding found previously by Plancher and Petersen (1984). The commercial rubberized asphalt used for crack and joint sealing survived the three-cycle extension test as would be expected of a commercial product designed for this use. However, visual inspection of these samples during the test revealed that there was some adhesive failure that occurred during each cycle of the test. Only portions of each sample separated from the concrete block and the parts remaining adhered to the block strongly enough to survive the test. Interestingly, the portions of each specimen that showed separation from the concrete block after extension healed themselves during the room temperature recompression step of the procedure.

Table 1. Results of ASTM D 3407 Extension and Resilience Testing on Unaged Materials

\begin{tabular}{lcccc}
\hline \multicolumn{1}{c}{ Sample } & \multicolumn{3}{c}{ Cycle } & $\begin{array}{c}\text { Resilience } \\
\text { Recovery, \% }\end{array}$ \\
\cline { 2 - 5 } & 1 & 2 & 3 & 0 \\
AC-20 failed & - & - & 1.5 \\
$\begin{array}{l}\text { AC-20+10\% shale- } \\
\text { oil additive }\end{array}$ & failed & - & - & 2.3 \\
$\begin{array}{l}\text { AC-20+20\% shale- } \\
\text { oil additive }\end{array}$ & failed \\
$\begin{array}{l}\text { Commercial rubberized } \\
\text { asphait }\end{array}$ & no failure & no failure & no failure & 40 \\
\hline
\end{tabular}

Note: All samples tested in triplicate 
The results of D 3407 (ASTM 1991b) extension testing of the AC-20 asphalt, the two shale-oil modified AC-20's, and the commercial rubberized asphalt after the 6-hour extended heating period are shown in Table 2 . These results exactly parallel the results for the untreated samples. This part of the test is designed to reflect any detrimental results that may occur after the sealant material is kept in a hot-pot during a normal working day. The purpose of this step is not to simulate long-term aging of the material.

Table 2. Results of ASTM D 3407 Extension Testing on Asphalt Samples After 6Hour Extended Heating

\begin{tabular}{lccc}
\hline \multirow{2}{*}{ Sample } & \multicolumn{3}{c}{ Cycle } \\
\cline { 2 - 4 } & failed & - & 3 \\
AC-20 & failed & - & - \\
AC-20+10\% shale-oil additive & failed & - & - \\
AC-20+20\% shale-oil additive & no failure & no failure & no failure \\
Commercial rubberized asphalt & & &
\end{tabular}

Note: All samples tested in triplicate

The resilience testing of these materials also shows that the addition of shale oil to the AC-20 asphalt improved the resilient properties of the asphalt. Although there is not a large measure of resilience displayed by the shale-oil modified asphalts compared with the commercial rubberized asphalt, there is a definite trend showing that the addition of shale oil to the AC-20 asphalt improved its resilient properties. Of course a relatively high level of resilience is expected of a material that contains over $15 \%$ rubber, as the commercial rubberized asphalt does.

The test conditions of ASTiM D 3407 are very severe for joint and crack sealing materials. However, another important factor in determining the success or failure of a sealant is the shape factor (Tons 1959). The shape factor is defined as the ratio of the width of the sealant to the depth. Different materials have different physical characteristics and can tolerate different shape factors. Method D 3407 prepares materials for extension testing that have a shape factor of $1: 4[1.27 \mathrm{~cm}: 5.08 \mathrm{~cm}(0.5 \mathrm{in} .:$ 2 in.)]. This shape factor results in very high strain levels being induced in the sealant material, whereas a shape factor of $1: 1$ results in strain levels of less than $50 \%$. 
The Federal Highway Administration recommends shape factors for bituminous materials of $1: 1$ with a minimum of $1: 2$ (Federal Highway Administration 1980). Obviously, ASTM test Method D 3407 imparts severe conditions on test materials to ensure that the materials will perform properly. However, the states of Wyoming and Colorado, and most likely many other states as well, use asphalt cements (e.g., AC-20) for crack and joint sealing (Lawes and LaForce, personal communication, 1992).

The results from the rheologic testing of portland cement concrete-asphalt briquets are shown in Table 3. This experiment is a stress-relaxation type of experiment where a stress is placed on a specimen, held fixed, and followed by the measurement of the relaxation that takes place. The objective of this experiment was to determine the rheological properties of the sealant materials while in contact with portland cement concrete. The relaxation time data from Table 3 are plotted versus temperature in Figure 3. Similar to the extension test results, Figure 3 shows that the commercial rubberized asphalt sealer is vastly different from the non-rubberized asphalts as would be expected. The addition of shale-oil additive to the AC-20 asphalt tends to shorten relaxation times compred with the AC-20 asphalt, however, at $0^{\circ} \mathrm{C}\left(32^{\circ} \mathrm{F}\right)$ the $10 \%$ shale-oil modified AC-20 asphalt has a longer relaxation time. It appea. "rom this data that there is an advantage gained by increasing the concentration of sha. sil additive to $20 \%$. There is a significant advantage of a faster relaxation time, especially at $0^{\circ} \mathrm{C} .\left(32^{\circ} \mathrm{F}\right)$. When the sealant material is placed under stress, a faster relaxation time translates to a better ability to relieve that stress.

The percent recovery data from Table 3 are plotted versus temperature in Figure 4. At all temperatures, the $20 \%$ shale-oil modified AC-20 asphalt shows the largest amount of recovery followed by the $10 \%$ shale-oil modified AC-20 asphalt and then the AC-20 asphalt. Again, there appears to be an advantage gained by the increased concentration of shale-oil additive. Interestingly, the commercial rubberized asphalt show " sssentially the same amount of recovery regardless of temperature. This is not a surpi ng fact due to the high concentration of rubber (more than 15\%) in this material. Th: $20 \%$ shale-oil modified asphalt has about the same amount of recovery at $0^{\circ} \mathrm{C}\left(32^{\circ} \mathrm{F}\right)$ as e commercial rubberized asphalt. The remaining amount of stress is stored as elasiac energy. In addition, the shale-oil modified asphalt and the AC-20 asphalt show rlmost complete recovery at $25^{\circ} \mathrm{C}\left(77^{\circ} \mathrm{F}\right)$. This fact is important because with warining, pavements expand, compressing the crack or joint. A material with a faster relaxation time and a larger amount of recovery should return to its original shape faster and more reliably than materials with slower relaxation times and lower amounts of recovery. This is important to avoid invasion of all foreign materials (water,dirt, etc.). 
Table 3. Relaxation Times and Percent Recovery Data from Portland Cement Concrete-Asphalt Briquets

\begin{tabular}{|c|c|c|c|}
\hline Sample & $\begin{array}{c}\text { Temperature, } \\
{ }^{\circ} \mathrm{C}\end{array}$ & $\begin{array}{l}\text { Relaxation } \\
\text { Time, sec. }\end{array}$ & $\begin{array}{l}\text { Percent } \\
\text { Recovery }\end{array}$ \\
\hline \multirow[t]{3}{*}{$\mathrm{AC}-20$} & $\begin{array}{c}25 \\
25 \\
\text { average }\end{array}$ & $\begin{array}{l}20 \\
14 \\
17\end{array}$ & $\begin{array}{l}98.0 \\
92.6 \\
95.0\end{array}$ \\
\hline & $\begin{array}{c}10 \\
10 \\
\text { average }\end{array}$ & $\begin{array}{l}180 \\
132 \\
156\end{array}$ & $\begin{array}{l}83.0 \\
76.0 \\
79.5\end{array}$ \\
\hline & $\begin{array}{c}0 \\
0 \\
\text { average }\end{array}$ & $\begin{array}{l}262 \\
281 \\
272\end{array}$ & $\begin{array}{l}41.0 \\
35.0 \\
38.0\end{array}$ \\
\hline \multirow[t]{3}{*}{ AC- $20+10 \%$ shale-oil additive } & $\begin{array}{c}25 \\
25 \\
\text { average }\end{array}$ & $\begin{array}{l}12 \\
20 \\
16\end{array}$ & $\begin{array}{l}98.0 \\
95.0 \\
96.5\end{array}$ \\
\hline & $\begin{array}{c}10 \\
10 \\
\text { average }\end{array}$ & $\begin{array}{c}154 \\
88 \\
121\end{array}$ & $\begin{array}{l}86.0 \\
91.5 \\
88.8\end{array}$ \\
\hline & $\begin{array}{c}0 \\
0 \\
\text { average }\end{array}$ & $\begin{array}{l}309 \\
280 \\
295\end{array}$ & $\begin{array}{l}26.0 \\
49.0 \\
37.5\end{array}$ \\
\hline \multirow[t]{3}{*}{ AC- $20+20 \%$ shale-oil additive } & $\begin{array}{c}25 \\
25 \\
\text { average }\end{array}$ & $\begin{array}{c}6 \\
10 \\
8\end{array}$ & $\begin{array}{l}98.5 \\
99.0 \\
98.7\end{array}$ \\
\hline & $\begin{array}{c}10 \\
10 \\
\text { average }\end{array}$ & $\begin{array}{l}90 \\
72 \\
81\end{array}$ & $\begin{array}{l}88.0 \\
91.4 \\
89.7\end{array}$ \\
\hline & $\begin{array}{c}0 \\
0 \\
\text { average }\end{array}$ & $\begin{array}{l}224 \\
262 \\
243\end{array}$ & $\begin{array}{l}62.0 \\
40.0 \\
51.0\end{array}$ \\
\hline \multirow[t]{3}{*}{ Commercial rubberized asphalt } & $\begin{array}{c}25 \\
25 \\
\text { average }\end{array}$ & $\begin{array}{l}86 \\
54 \\
70\end{array}$ & $\begin{array}{l}53.0 \\
47.5 \\
50.3\end{array}$ \\
\hline & $\begin{array}{c}10 \\
10 \\
\text { average }\end{array}$ & $\begin{array}{l}108 \\
112 \\
110\end{array}$ & $\begin{array}{l}53.8 \\
49.0 \\
51.4\end{array}$ \\
\hline & $\begin{array}{c}0 \\
0 \\
\text { average }\end{array}$ & $\begin{array}{l}64 \\
73 \\
69\end{array}$ & $\begin{array}{l}56.5 \\
57.9 \\
57.2\end{array}$ \\
\hline
\end{tabular}




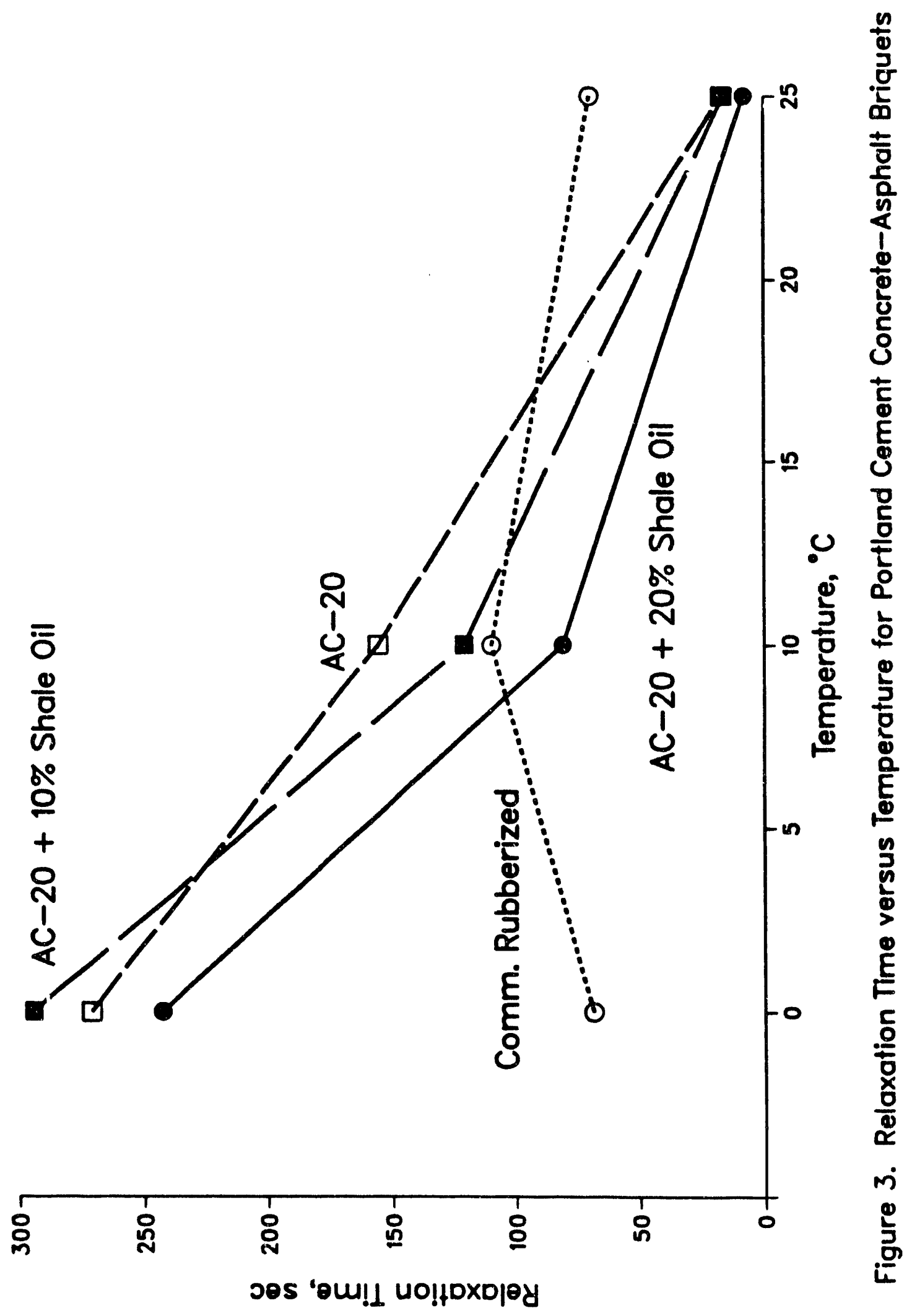




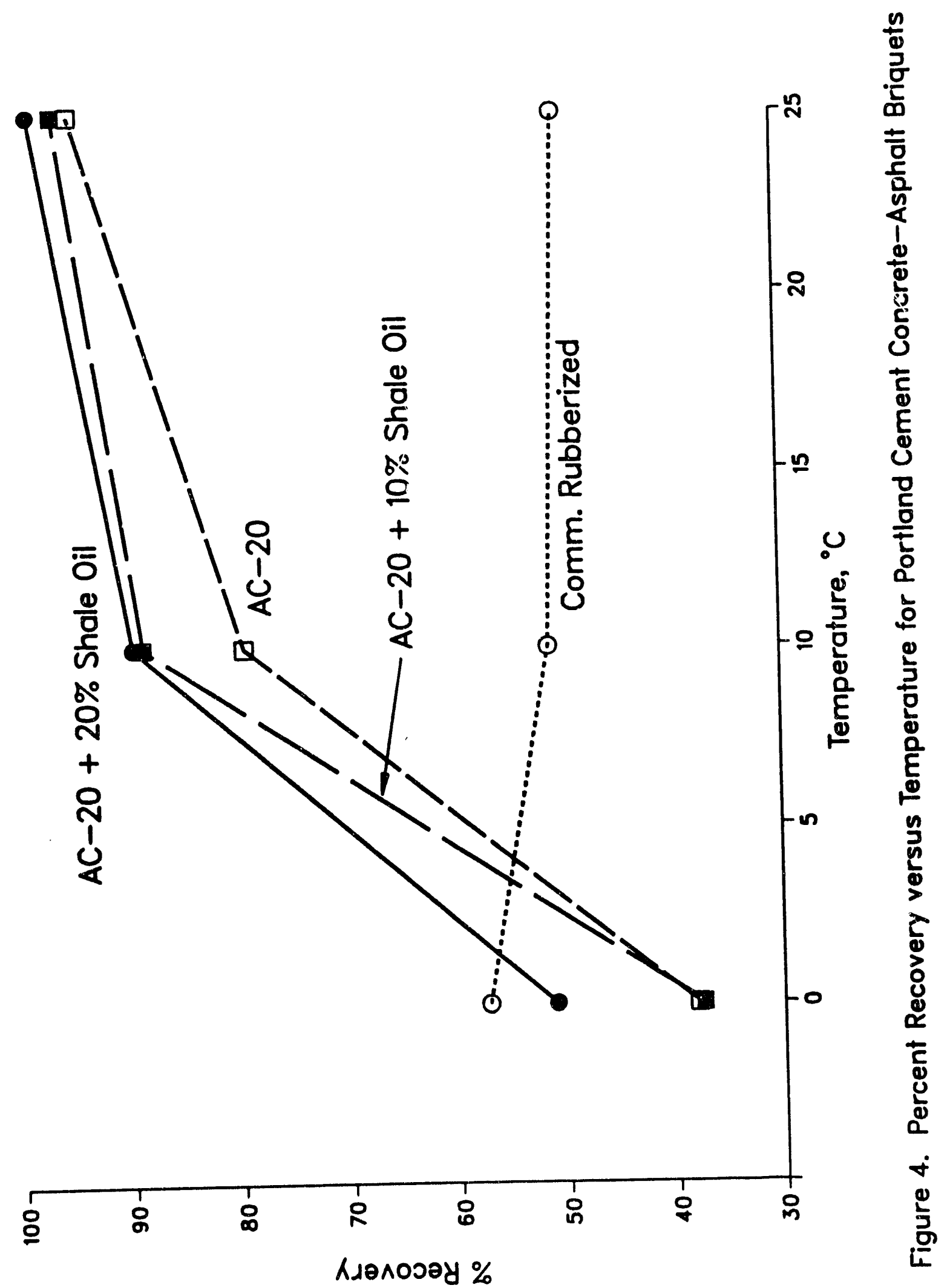




\section{CONCLUSIONS}

The addition of a shale-oil additive to a petroleum asphalt did not result in acceptable performance in the very severe ASTM D 3407 extension test. However, the shape factor of the sealant material in the extension test is not ideal for strictly bituminous materials. The addition of the shale-oil additive to a petroleum asphalt did show improvement in the resilience of the material as measured by the resilience test in ASTM D 3407. The shale-oil modified asphalts also showed improved adhesion properties compared with the AC-20 asphalt.

The addition of shale oil to a petroleum asphalt, especially at the $20 \%$ level, showed faster relaxation times and larger amounts of recovery in a stress-relaxation type of test using portland cement concrete-asphalt briquets.

Finally, shale-oil modified asphalt shows some unique properties when tested as a crack and joint sealant material for use in asphaltic and portland cement concrete pavements. The better adhesion property shown in the extension test could be a very valuable property in the use of this material. Although the cost of a shale-oil modified asphalt material would be higher than the comparable petroleum asphalt, it would probably be substantially cheaper than commercial rubberized asphalt products and this may be a tenefit for its potential use. In particular, the life cycle cost of using the shaleoil modified crack and joint fiier may be improved in cases where conventional asphalts would otherwise be used. 


\section{ACKNOWLEDGMENTS}

The authors express thanks and appreciation to the United States Department of Energy for funding this work under Cooperative Agreement Number DE-FC21$86 \mathrm{MC1} 1076$. Appreciation is also extended to the following people at Western Research Institute who contributed to the completion of this project: Jane Tauer, Felicia Reid, Alisa Gwin, Mary Aldrich, and Deborah Colgin.

\section{DISCLAIMER}

Mention of specific brand names or models of equipment is for information only and does not imply endorsement by Western Research Institute or the United States Department of Energy. 


\section{REFERENCES}

ASTM, 1991a, ASTM Standard C 192, Standard Practice for Makin's and Curing Concrete Test Specimens in the Laboratory. American Society for Testing and Materials, Philadelphia, PA.

ASTM, 1991b, ASTM Standard D 3407, Standard Methods of Testing Joint Sealants, Hot-Poured, for Concrete and Asphalt Pavements. American Society for Testing and Materials, Philadelphia PA.

ASTM, 1991C, ASTM Standard D 5, Standard Test Method for Penetration of Bituminous Materials. American Society for Testing and Materials, Philadelphia PA.

Federal Highway Administration, 1980, Rigid Pavement Joints. FHWA Technical Advisory T5140.18, U.S. Department of Transportation, Washington, DC.

Hogan, R.A., 1980, Preventative Maintenance Methods for Highway Pavements. New Hampshire Department of Public Works and Highways. Paper presented at Pothole Workshop, U.S. Army Cold Regions Research and Engineering Laboratory.

Peterson, D.E., 1982, Resealing Joints and Cracks in Rigid and Flexible Pavements. National Cooperative Highway Research Program Synthesis of Highway Practice No. 98.

Plancher, H., and J.C. Petersen, 1984, Nitrogen-Containing Components from Shale Oil as Modifiers in Paving Applications. Preprints, Division of Petroleum Chemistry, American Chemical Society, 29(1): 229-237.

The Asphalt Institute, 1989, The Asphalt Handbook. The Asphalt Institute Manual Series No. 4. MS-4, p.7.

Tons, E., 1959, A Theoretical Approach to Design of a Road Joint Seal. HRB Bulletin 229, Highway Research Board, National Research Council, Washington, DC, pp. 20-53.

Wolters, R.O., 1974, Field Evaluation of Joint Seal Materials, Final Report. Minnesota Department of Highways. 

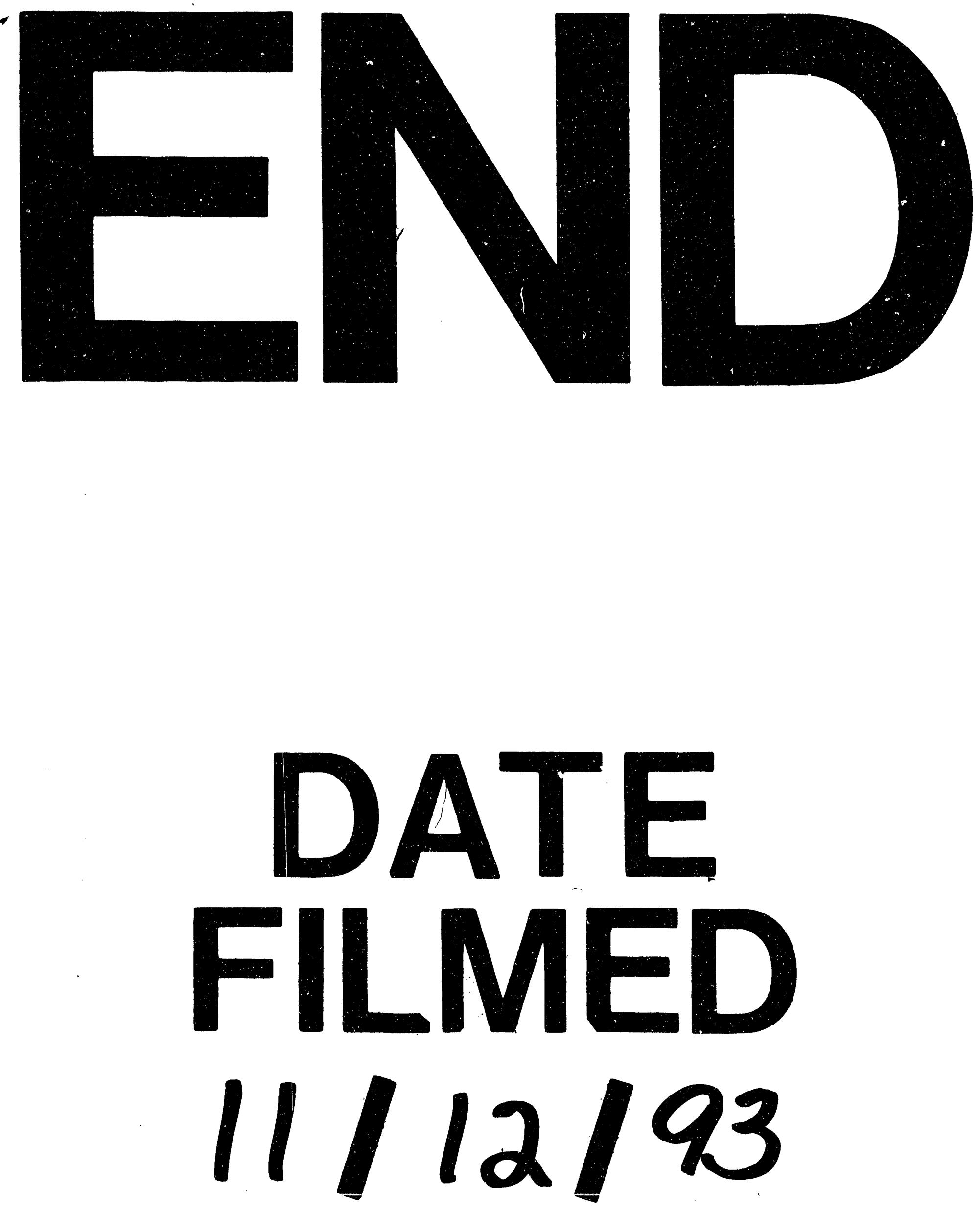

1 
